\title{
Seeds Treatment Using Trichoderma spp. Formulated in Biosluryy and Vermicompost to Induct the Resistance of the Peanut (Arachis hypogaea. L) Diseases
}

\author{
I. Made Sudana* and I. Gusti Ngurah Raka
}

Faculty of Agricultural, Udayana University. Indonesia

*Corresponding author

\section{Keywords \\ Peanut, Rhizobium, Systemic acquired resistance (SAR), PGPR, \\ Vermicompost, Biosluryy. Paddy fields}

Article Info

Accepted: 12 September 2020 Available Online: 10 October 2020

\section{A B S T R A C T}

From the results of several studies it is suspected that even though there is a Rhizobium microbial field that can provide nitrogen for plants, it is thought that very little population lives around the roots. In addition, few microbes are able to spur plant growth, namely Plant Growth Promoting Rhizobacteria (PGPR) Bacteria. And systemic inducing microbes or Systemic acquired resistance (SAR) to plant pathogens, even though microbes are only given to the roots, will be able to increase the resistance of all parts of the plant to disease. So in an effort to increase peanut production, research is needed to get systemic resistanceinducing microbes (SAR), using the Trichoterma spp, and as a Fungus carrier media is Vermicompost fertilizer and Biosluryy fertilizer fertilizer is rich in nutrients. The mixture between Trichoderma and its carrier is formulated as biofertilizer and this biofertilizer will be applied as a seed treatment, ie biofertilizer is mixed with seeds before being planted. It is expected that from the results of this study peanut plants will have good growth and production as well as disease resistance. From the results of the study, it was found that peanut seeds after being given seed treatment, Trichoderma koningii, $T$. viride, $T$. asperelum, T. reseii and T. asperelum formulated in Vermicompost or Bioslury fertilizer were very good in increasing the growth and production of peanuts. compared Control (only using Vermicompost and Bioslury without Trichoderma. Trichoderma which is formulated in Vermicompost fertilizer has better ability to increase plant growth compared to bioslury fertilizer. Trichoderma asperelum is the best Trichoderma if applied to peanut plants in formulations with Vermicompost fertilizer both in veetative growth and generative growth of peanut plants. And cause the peanut is able to produce up to 3.9 tons / Ha while the Control is only 1.65 tons per Ha as well as if Trichoderma has been formulated in Bioslury fertilizer, the peanut plant is able to produce 3.70 Tons / Ha. So in an effort to increase peanut production to reach 3.9 tons / ha it is better to use Trichoderma Asperelum formulated in vermicompost or bioslury fertilizer. In terms of increasing disease resistance it turns out that Trichoderma asperilium either formulated in vermicompost fertilizer or bioslury fertilizer has the lowest infection rate against Mottle virus as much as $3.60 \%$ to $4.13 \%$ or leaf rust disease (Puccinia arachidis) with an intensity of infection of $15.70 \%$ and $14.06 \%$. 


\section{Introduction}

According to Harman, (2000), Trichoderma spp. Is a fungus that lives in the soil and likes to live on the surface of the roots of plants, by utilizing the root exudate in his life. If Trichoderma spp, already found the roots quickly the fungus roams the roots and wraps the roots and protects plants from disease. Trichoderma spp., In addition to being hyperparasitic and mycoparasitic, as well as antibiosis but also able to induce the host's resistance to pathogens (Agrios, 2005; Sudantha et al., 2014). According to Heil and Bostok (2002) in Syahri (2011), induction of plant resilience can occur in two ways, namely by directly producing pathogenesisrelated protein $(\mathrm{PR})$ and phytoalexin as a result of attacks by pathogenic microorganisms that are inhibited growth.

Thereby Trichoderma spp is very suitable to be applied as Seed treatment (seed treatment) with carrier carrying media Vermicompost or bioslurry (biogas waste), because Vermicompost and Biogas Waste is also rich in beneficial Microorganisms, namely as a phosphate solvent and nitrogen fixing from air so that it can be In addition, according to Harman, (2000), Trichoderma spp, which is attached to the roots of plants, also forms mycelia that can spread and extend beyond the root of an area of 1 meter or more, the hyphae will suck water and nutrient elements and carry near the roots of plants, this also helps plant enough water and nutrients in the cells. So the use of Trichoderma spp, which is formulated in Vermicompost and bioslurry is expected to increase peanut production (Hidayat and Mulyani, 2002).

Peanut plants can meet their nitrogen needs by conducting symbiosis with nitrogen-fixing bacteria from the air, namely Rhizobium bacteria, but the symbiotic mechanism between peanut plants and Rhizobium is often disrupted by physical, chemical and biological soil conditions (Sprent, 1976). In environmental conditions that meet the growing requirements, the symbiosis that occurs is able to meet $50 \%$ or even the entire nitrogen needs of the plant concerned by capturing free nitrogen (Saono, 1981). In addition, the Rhizobium bacterium has a positive impact both directly and indirectly on the physical and chemical properties of the soil, so as to increase soil fertility (Alexander, 1977).

In paddy soils, phosphate is generally very low available for plants, so to meet the availability of phosphate in the soil, it is necessary that Rhizobacteria solvent phosphate from solanaceae is able to dissolve phosphate that is bound to grains of soil organic matter, but can also stimulate the growth of Rhizobium bacteria (Rao, 1994).

So to increase the growth of Rhizobium in the soil, it is necessary to look for bacteria that live on the surface of the roots of plants (Rhizobacteria) and be able to stimulate the growth of Rhizobium bacteria, so that Rhizobium bacteria form more nodules forming nodules and more plants get nitrogen intake from the air so that plant growth becomes fertile and healthy. With good plant growth, the plant will produce exudates on the root surface of the plant, the exudate is rich in protein, carbohydrates and vitamins needed for the survival of Rhizobacteria in peanut roots.

\section{Materials and Methods}

The research was conducted at the Plant Disease Laboratory, Faculty of Agriculture, Udayana University and in the field in the Renon area which often cultivates peanuts. Field research was conducted to observe the ability of Trichoderma spp in stimulating Rhizobium bacteria to form root nodules on 
plants and stimulate the growth of peanuts and stimulate peanut resistance. against disease attacks in the field, the stages of research include;

\section{Propagation of Trichoderma spp.}

The Trichoderma spp was obtained from the Microbiology Laboratory at the Bandung Institute of Technology and from the Biotechnology Laboratory of the Faculty of Agriculture, Udayana University, which consisted of

\section{Tricoderma koningii,}

Tricoderma viride,

Tricoderma asperelum

Tricoderma harzianum

Trichoderma reesei

Tricoderma asperelum $\mathrm{RS}$

This Trichoderma is cultured on the media of Potato Pepton Glucose In order to restore its ability as a microbial antagonist or its ability as a Systemic acquired resistance (SAR) or induction of systemic resistance

\section{Preparation of bioslurry and vermicomposting}

Bioslurry which is a biogas reactor from cow dung is obtained from Simantri Pedawa, Pedawa Village, Banjar Singaraja sub-district, while Vermicompost fertilizer is obtained from the earthworm cultivation site CV. Bali Organic Agriculture in Denpasar belongs to Dr. Kartini.

Making bioslurry and vermicompost formulations as Trichoderma biofertilizer in peanut plants

Prepared sources of Trichoderma spp inoculums were cultured respectively in liquid Potato peptone glucose (PPG) media in the Shaker and incubated for 4-5 days until the media appeared turbid and full of Trichoderma spp, then bioslurry was prepared and the raw material came from manufacturing waste. Cow manure in biogas. And Vermicompost obtained from the Worm farm CV. BOA Media bioslurry and vermicompost each pack in plastic bags each of $500 \mathrm{~g}$ and 10 grams of granulated sugar and $50 \mathrm{~g}$ of wood charcoal flour, to neutralize $\mathrm{pH}$, and stir evenly, then cold compost media, the media inoculated with $250 \mathrm{ml}$ each. Trichoderma spp. Furthermore, compost media that have been inoculated with Trichoderma spp are incubated for 7 days, while each day the culture is stirred.

\section{Preparation of rhizobium bacteria inoculum source}

The best Rhizobium isolate bacterium obtained in the study was Rhizobium Btl 8 . This bacterium was cultured on liquid YEM (Yeast Extract Mannitol) media and incubated for 3 days. then the bacterial solution was diluted to obtain a concentration of $106 \mathrm{cfu} /$ $\mathrm{ml}$ Rhizobium bacteria then $1 \mathrm{ml}$ of Rhizobium bikan was inoculated on compost formulation media to be applied to peanut plants together with Trichoderma formulations as above.

\section{Application of Trichoderma spp biofertilizer in peanut plants by seed treatment}

Before the peanut seeds are planted in the plot of the experiment, the seeds are given Biofertilizer Trichoderma by seed treatment

1. For Trichoderma spp Biofertilizer formulated in the form of Compost, as many as 150 seeds of peanut seeds can be mixed with Biofertilizer until it is evenly distributed, that is, it appears that all seed surfaces are covered by Biofertilizer Trichoderma spp and the seeds are directly planted. 
2. Provision of Rhizobium Btl 8 bacteria can be given to the seeds by mixing groundnut seeds that have been treated with Trichoderma spp Biofertilizer Imbibition, then the seeds can be directly planted into the experimental plot in accordance with the treatment

\section{Planting peanut seeds that have received Biofertilizer treatment}

\section{Trichoderma spp in paddy field}

The field research was carried out as the best adaptation test of Biofertilizer Trichoderma spp test results in the laboratory, the aim of which was to determine the stability of these microbes in stimulating the growth and production of peanut plants and resistance to disease in the field at that time.

It also stimulates Rhizobium bacteria to form nodules on peanut plants in the field, but in this field research, Trichoderma spp was formulated first into biofertilizer using the method of Hanuddin et al., (2010), field research was carried out using a RAK research design using 3 replications, varieties of peanuts in plants were local varieties, the treatments being tested were:

\section{Biofertilizer formulation carrier media}

1. Bioslurry ctompos

2. Vermicompost

Trichoderma spp is able to induce plant growth

Tricoderma koningii,

Tricoderma viride,

Tricoderma asperelum

Tricoderma harzianum

Tricoderma reseii

Tricoderma asperelum $\mathrm{RS}$

\section{Control treatment}

Peanuts are planted according to local farmers' habits. How to plant them does not provide biofertilizer,

\section{Planting}

Peanut seeds that have been treated with Seed Treatments Biofertilizer Trichoderma spp are planted in the field with a plant spacing of 20 $X 20 \mathrm{~cm}$ in a cultivated plot with a depth of $15 \mathrm{~cm}$, plot size $1 \mathrm{X} 2 \mathrm{M}$, each planting hole is filled with 3 seeds, and after growing in the perarang into one plant per hole, the plants are kept well until harvest while observing

Height of peanut plants

Number of leaves, flowers and pods

Chlorophyll content in peanut leaves

Weight of seeds and seed production per plant Number and weight of nodules per plant The type and intensity of damage to diseases affecting plants is measured using methods;

The intensity of plant disease (Boggie \& Hans, 1988)

$$
\mathrm{I}=\Sigma \frac{(\mathrm{n} \mathrm{x} \mathrm{v})}{\mathrm{ZN}} \times 100 \%
$$

Information

$\mathrm{I}=$ intensity of attack on leaf spot disease

$\mathrm{n}=$ Number of plants showing symptoms of leaf spot disease

$\mathrm{v}=$ Numerical price value (Score) of each category

$\mathrm{Z}=$ Value score from the highest category

$\mathrm{N}=$ number of peanut plants

\section{Results and Discussion}

After the treatment of peanut seeds with antagonistic fungi on several pathogens then the seeds were planted in paddy fields in the Sanur area, at first it appeared that the treatment of seed treatment using the fungus Trichoderma spp, apparently the growth of seedlings was somewhat stunted, but after the seeds grew, the seedlings grew quite quickly; 


\section{Vegetative growth of peanut plants}

\section{Plant height}

After the peanut seeds were given seed treatment, Trichoderma koningii, T.viride, T. asperelum, $T$. reseii and $T$. asperelum $\mathrm{RS}$ showed that there was a difference between the seeds planted on the land using vermicompost fertilizer, the growth was better than bioslurry fertilizer, this is because Vermicompost fertilizer is a fertilizer used for the cultivation of earthworms made by earthworm entrepreneurs.

This can be seen in Table 1 that peanuts that received Trichoderma treatment and given Vermicompost fertilizer have higher growth compared to the use of bioslurry fertilizer (Biogas Installation Waste). But from the type of Trichoderma, it turns out that Trichoderma koningii has not been good growth

\section{Number of plant branches}

Same with plant height observations, in Table 1 , it turns out that the use of vermicompost fertilizer the number of branches produced by the plant is more than the plants that are fertilized with bioslurry, so vermicompost fertilizers are able to fertilize plants, because the vermicompost contains high nutrient and micro nutrient elements (Kuruparan, 2005).

When viewed from the antagonistic fungus, it turns out that $\mathrm{T}$. koningii with the vermicompost fertilizer carrier and $T$. asperelum with the bioslurry fertilizer carrier, are also able to increase the number of peanut branches and differ from control.

\section{Number of leaves of peanuts}

In table 1, it appears that the number of leaves produced by peanut plants applied with Vermicompost or bioslurry fertilizer, a slight difference in terms of increasing the number of plant leaves, but it is clearly seen that controls that are only given bioslurry without being given Trichoderma, the number of leaves is very low, while the control is only given vermicompost but without Trichoderma the number of leaves is quite a lot, here it is clear that organic vermicompost fertilizer is able to increase the growth of peanut plants

\section{Leaf area of peanut leaves}

In Table 1, it appears that the area of peanut leaves that are only given Vermicompost or bioslurry fertilizer, without being given Trichoderma, the area of the daa produced is smaller than the kascin and bioslurry fertilizers that are treated with Trichoderma.

According to some researchers, Trichoderma states that in addition to being a natural enemy of the pathogen, it also has the nature of a phosphate element solvent in the soil so that it is available for plants with sufficient $P$ elements, the leaf area widens and also adds to the chlorophyll of the leaf.

\section{Chlorophyll content in leaves}

The chlorophyll content in peanut leaves can be seen in Table 1, it appears that the treatment of vermicompost fertilizer gives more amount of chlorophyll than bioslurry, although it does not give trichoderma. The seed treatment using $T$. asperelum, with bioslurry carrier produced the highest number of chlorophyll compared to other treatments.

\section{Generative growth of peanut plants}

Number of root nodules (Rhizobium Sp) /plant

After the peanut seeds were given seed treatment treatment, Trichoderma koningii, T.viride, $T$. asperelum, $T$. reseii and $T$. 
asperelum RS appeared to be no difference between the seeds planted on land using vermicompost fertilizers. The growth was better than bioslurry fertilizer. this is because Vermicompost fertilizer is a fertilizer used for the cultivation of earthworms made by earthworm entrepreneurs. This can be seen in Table 2, that the peanuts that received treatment given earthworm fertilizer (Vermicompost) growth appeared higher compared to the use of bioslurry fertilizer (Biogas Installation Waste), because the vermicompost fertilizer contained microelement nutrients and growth hormones, higher than bioslurry fertilizer, as a result of good plant growth and increased production of peanut seeds. With the good growth of bean plants, the roots of the sign more and more formed, with the number of hair roots formed is a good opportunity for Rhizobium to enter into the root and live in the root cell and capture nitrogen from the air into the root (Fig. 1)

Table.1 Skor (nilai numerik) intensitas serangan penyakit Bercak daun (Sarwono, 1995)

\begin{tabular}{|c|l|}
\hline Score & Percentage of leaf spot symptoms (\%) \\
\hline 0 & No symptoms of 0\% disease, no symptoms of leaf spot \\
\hline 3 & Symptoms are mild, $1 \%-15 \%$ show symptoms of leaf spot \\
\hline 5 & Symptoms are moderate, $16 \%-35 \%$ show symptoms of leaf spot \\
\hline 7 & Symptoms are severe, $36 \%-75 \%$ show symptoms of leaf spot \\
\hline 9 & Symptoms are very severe, $76 \%$ - 100\% show symptoms leaf spot \\
\hline
\end{tabular}

Table.2 Vegetative growth of plants due to the use of Trichoderma and biological fertilizers

\begin{tabular}{|c|c|c|c|c|c|c|}
\hline $\begin{array}{c}\text { Carrier } \\
\text { Type } \\
\text { (Fertilizer) }\end{array}$ & $\begin{array}{c}\text { Kind of } \\
\text { Trichoderma }\end{array}$ & $\begin{array}{l}\text { Plant } \\
\text { height } \\
(\mathbf{C m})\end{array}$ & $\begin{array}{c}\text { Number } \\
\text { of } \\
\text { branches }\end{array}$ & $\begin{array}{c}\text { Number } \\
\text { of leaves } \\
\text { (sheet) }\end{array}$ & 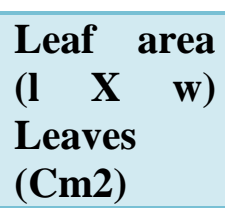 & $\begin{array}{l}\text { Chlorifil } \\
\text { in the } \\
\text { leaves } \\
\text { (SPAD) }\end{array}$ \\
\hline \multirow{7}{*}{$\begin{array}{l}\text { Vermicom } \\
\text { post }\end{array}$} & T. koningii & $55.67 \mathrm{~b}$ & 7.00 & $68.67 \mathrm{de}$ & $55.04 \mathrm{~b}$ & 40.10 \\
\hline & T. viride & $59.33 c$ & 6.67 & $67.67 \mathrm{~cd}$ & $60.61 d$ & 40.47 \\
\hline & T. asperelum & $59.00 \mathrm{c}$ & 6.67 & $71.00 \mathrm{e}$ & $63.99 \mathrm{e}$ & 39.17 \\
\hline & T. harzianum & $59.50 \mathrm{c}$ & 5.33 & $66.33 c$ & $63.75 \mathrm{e}$ & 40.03 \\
\hline & T. reseii & $56.67 b c$ & 5.67 & $69.67 \mathrm{~cd}$ & $59.02 \mathrm{~cd}$ & 39.00 \\
\hline & T.asperelum-RS & $59.03 c$ & 4.67 & $67.00 \mathrm{c}$ & $61.20 \mathrm{~d}$ & 38.57 \\
\hline & Control & $50.50 \mathrm{a}$ & 5.33 & $68.67 \mathrm{~cd}$ & $55.04 \mathrm{~b}$ & 39.33 \\
\hline \multirow{7}{*}{ Bioslurry } & T. koningii & $51.13 \mathrm{a}$ & 5.66 & $54.33 \mathrm{ab}$ & $52.69 \mathrm{ab}$ & 38.49 \\
\hline & T. viride & $51.17 \mathrm{a}$ & 6.33 & $57.33 b$ & $58.74 \mathrm{~cd}$ & 37.6 \\
\hline & T. asperelum & $56.33 b c$ & 7.00 & $62.00 \mathrm{c}$ & $68.01 \mathrm{e}$ & 42.30 \\
\hline & T. harzianum & $54.93 \mathrm{a}$ & 6.33 & $61.67 \mathrm{~b}$ & $54.32 \mathrm{~b}$ & 36.48 \\
\hline & T. reseii & $55.10 \mathrm{~b}$ & 6.33 & $59.67 \mathrm{~b}$ & $54.79 b$ & 36.04 \\
\hline & T. asperelum-RS & $54.03 \mathrm{ab}$ & 6.33 & $60.67 b c$ & $62.49 \mathrm{~d}$ & 40.54 \\
\hline & Control & $48.77 \mathrm{a}$ & 5.00 & $47.00 \mathrm{a}$ & $50.64 a$ & 36.18 \\
\hline
\end{tabular}


Table.3 Generative plant growth due to Trichoderma and biological fertilizers

\begin{tabular}{|c|c|c|c|c|c|}
\hline $\begin{array}{c}\text { Carrier Type } \\
\text { (Fertilizer) }\end{array}$ & $\begin{array}{c}\text { Kind of } \\
\text { Trichoderma }\end{array}$ & $\begin{array}{c}\text { Number of } \\
\text { Root } \\
\text { Nodule / } \\
\text { plant }\end{array}$ & $\begin{array}{c}\text { Fresh } \\
\text { Weight a } \\
\text { crop/ plants } \\
\text { (g) }\end{array}$ & $\begin{array}{l}\text { Number of } \\
\text { Pods } \\
\text { Containing } \\
\text { seeds/Plant }\end{array}$ & $\begin{array}{l}\text { Weight of Pods } \\
\text { Containing } \\
\text { seeds/Plant (g) }\end{array}$ \\
\hline \multirow{7}{*}{ Vermicompost } & T. koningii & $217 \mathrm{c}$ & $126 c$ & $33 \mathrm{~cd}$ & $45.24 \mathrm{a}$ \\
\hline & T. viride & $311 d$ & $129 \mathrm{~cd}$ & $29 \mathrm{bc}$ & $64.83 \mathrm{~cd}$ \\
\hline & T. asperelum & $305 d$ & $157 \mathrm{de}$ & $31 \mathrm{bc}$ & $73.34 d$ \\
\hline & T. harzianum & $304 d$ & $154 d$ & $40 \mathrm{~d}$ & $58.26 \mathrm{~b}$ \\
\hline & T. reseii & $179 b c$ & $164 \mathrm{e}$ & $33 \mathrm{~cd}$ & $48.42 \mathrm{a}$ \\
\hline & T.asperelum-RS & $289 \mathrm{~cd}$ & $145 d$ & $31 \mathrm{bc}$ & $63.53 \mathrm{~cd}$ \\
\hline & Control & $217 \mathrm{c}$ & $123 \mathrm{c}$ & $23 b c$ & $39.34 \mathrm{a}$ \\
\hline \multirow{7}{*}{ Bioslurry } & T. koningii & $127 \mathrm{a}$ & $96.58 b$ & $20 \mathrm{a}$ & $52.76 b$ \\
\hline & T. viride & $137 \mathrm{a}$ & $95.67 \mathrm{~b}$ & $21 \mathrm{ab}$ & $62.00 \mathrm{~b}$ \\
\hline & T. asperelum & $136 \mathrm{a}$ & $97.58 \mathrm{c}$ & $22 \mathrm{~b}$ & $63.78 \mathrm{~cd}$ \\
\hline & T. harzianum & $137 \mathrm{a}$ & $102.83 \mathrm{c}$ & $18 \mathrm{a}$ & $47.27 \mathrm{a}$ \\
\hline & T. reseii & $152 b$ & $93.67 \mathrm{a}$ & $20 \mathrm{a}$ & 51.72ab \\
\hline & T. asperelum-RS & $100 \mathrm{a}$ & $99.83 \mathrm{c}$ & $21 \mathrm{ab}$ & $56.79 b$ \\
\hline & Control & $122 \mathrm{a}$ & $77.83 \mathrm{a}$ & $14 \mathrm{a}$ & $33.22 \mathrm{a}$ \\
\hline
\end{tabular}

Table.4 Crop production due to Trichoderma and biological fertilizers

\begin{tabular}{|c|c|c|c|c|}
\hline $\begin{array}{c}\text { Carrier Type } \\
\text { (Fertilizer) }\end{array}$ & $\begin{array}{c}\text { Kind of } \\
\text { Trichoderma }\end{array}$ & $\begin{array}{c}\text { Number of } \\
\text { seeds / plants }\end{array}$ & $\begin{array}{l}\text { Seed weight / } \\
\text { plant (g) }\end{array}$ & $\begin{array}{c}\text { Peanut Seed } \\
\text { Production (Ton } \\
\text { / Ha) }\end{array}$ \\
\hline \multirow{7}{*}{ Vermicompost } & T. koningii & $58 \mathrm{bc}$ & $45.28 \mathrm{c}$ & $3.84 \mathrm{~d}$ \\
\hline & T. viride & $50 \mathrm{a}$ & $30.29 a$ & $2.57 \mathrm{a}$ \\
\hline & T. asperelum & $80 \mathrm{~d}$ & $46.14 c$ & $3.92 \mathrm{~d}$ \\
\hline & T. harzianum & $66 \mathrm{~cd}$ & $40.41 \mathrm{c}$ & $3.43 \mathrm{~cd}$ \\
\hline & T. reseii & $66 \mathrm{~cd}$ & $33.66 \mathrm{ab}$ & $2.86 \mathrm{~b}$ \\
\hline & T.asperelum-RS & $64 \mathrm{~cd}$ & $42.86 \mathrm{c}$ & $3.64 d$ \\
\hline & Control & $49 \mathrm{a}$ & $31.48 \mathrm{a}$ & $1.67 \mathrm{a}$ \\
\hline \multirow{7}{*}{ Bioslurry } & T. koningii & $59 \mathrm{bc}$ & $38.88 \mathrm{~b}$ & $3.30 \mathrm{c}$ \\
\hline & T. viride & $61 \mathrm{c}$ & $40.64 b c$ & $3.45 \mathrm{~cd}$ \\
\hline & T. asperelum & $64 \mathrm{~cd}$ & $43.71 b c$ & $3.71 \mathrm{~d}$ \\
\hline & T. harzianum & $53 \mathrm{ab}$ & $29.63 a$ & $2.51 \mathrm{a}$ \\
\hline & T. reseii & $57 \mathrm{~b}$ & $32.69 \mathrm{a}$ & $2.77 \mathrm{~b}$ \\
\hline & T. asperelum-RS & $57 \mathrm{~b}$ & $34.85 a b$ & $2.96 b c$ \\
\hline & Control & $32 a$ & $19.72 \mathrm{a}$ & $1.45 \mathrm{a}$ \\
\hline
\end{tabular}


Table.5 The level of damage due to virus strips and leaf rust disease

\begin{tabular}{|c|l|c|c|}
\hline $\begin{array}{c}\text { Carrier Type } \\
\text { (Fertilizer) }\end{array}$ & \multicolumn{1}{|c|}{$\begin{array}{c}\text { Kind of } \\
\text { Trichoderma }\end{array}$} & $\begin{array}{c}\text { Disease rate of the Striped } \\
\text { Virus (\%) }\end{array}$ & $\begin{array}{c}\text { Intensity of Leaf Rust } \\
\text { Disease (\%) }\end{array}$ \\
\hline & T. koningii & 9.46 & 30.30 \\
\cline { 2 - 4 } & T. viride & 6.10 & 18.30 \\
\cline { 2 - 4 } Vermicompost & T. asperelum & 3.60 & 15.70 \\
\cline { 2 - 4 } & T. harzianum & 6.50 & 22.04 \\
\cline { 2 - 4 } & T. reseii & 6.03 & 33.93 \\
\cline { 2 - 4 } & T.asperelum-RS & 10.40 & 34.25 \\
\cline { 2 - 4 } & Control & 30.86 & 55.79 \\
\hline \multirow{5}{*}{ Bioslurry } & T. koningii & 7.23 & 43.33 \\
\cline { 2 - 4 } & T. viride & 16.60 & 28.72 \\
\cline { 2 - 4 } & T. asperelum & 4.13 & 14.06 \\
\cline { 2 - 4 } & T. harzianum & 5.56 & 29.33 \\
\cline { 2 - 4 } & T. reseii & 6.20 & 33.50 \\
\cline { 2 - 4 } & T. asperelum-RS & 6.30 & 66.83 \\
\cline { 2 - 4 } & Control & 28.76 & 60.45 \\
\hline
\end{tabular}

Fig.1
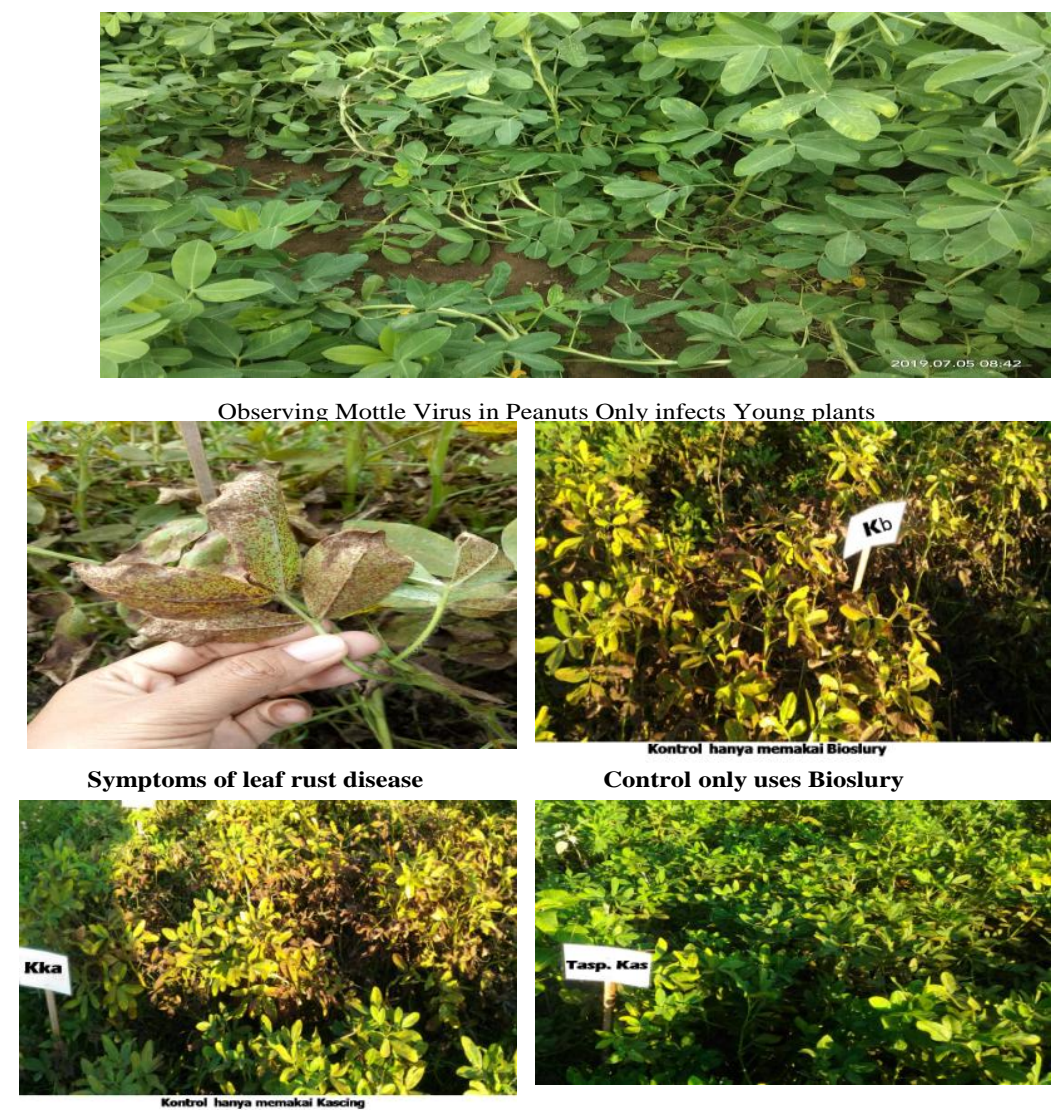

Control only uses Vermicompost

T. asperelum with Vermicompost carrier 


\section{Fresh weight of stover / plants}

In Table 2 it appears that the application of Vermicompost organic fertilizer produces plant growth that is far better than the provision of bioslurry fertilizer on peanut plants, this is clear because the macro and micro nutrient elements in vermicompost fertilizer are far more complete than bioslurry. In addition, it is also said high levels of ZPT hormone content (Tiunov et al., 2002). Microbials of $T$. asperelum, T. harzianum and T. recipei with Vermicompost fertilizer carriers produce the highest crop stover weight when compared with other treatments, thus it appears that the carrier media of vermicompost fertilizer is also able to increase Trichoderma pupil compared to bioslurry (Munroe, 2003; Kuruparan, 2005)

\section{Number of pods containing / plant}

Peanut plants that received Trichoderma treatment with vermicompost fertilizers produced a much higher number of pods containing plantations compared to Tricohoderma with bioslurry carriers, possibly with Vermicompost carriers (Table 2) Trichoderma was more susceptible than bioslurry carriers. Likewise, plants which were only given a vermicompost amount of pods were much higher than bioslurry fertilizer, and T. harzianum treatment with vermicompost carriers resulted in the highest number of pods containing compared to other treatments.

\section{Weight of contained pods / plants}

In Table 2, it appears that tanman which is only given a vermicompost fertilizer and Biosluri fertilizer without microbial Trichoderma (Control) has the ability to produce the smallest pod weight compared to the fertilizer given Trichoderma, here it is clear that Trichoderma is indeed true as can help the availability of phosphate elements and produce phytohormone, IAA, Geberelin, which is able to stimulate plants to form a lot of hair roots, with the number of roots formed by the hair will make it easier for the Rhizobium bacteria to enter the plant roots and help provide nitrogen for plants, while also able to provide nitrogen for plants (Harman 2000). From the observation it turns out that $T$. asperelum with Vermicompost carriers has the ability to increase the weight of filled pods compared to laiina treatment.

\section{Number of seeds / plant}

In table 3, it appears that the control plants (only given Vermicompost fertilizer or bioslurry fertilizer without Trichoderma, produced a much lower number of seeds compared to plants treated with Trichoderma. This is clear because Trichoderma as a fungus that can provide $\mathrm{N}$ and $\mathrm{P}$ fertilizers is also able to provide growth hormone for plants. In table 3 , it can be seen that $\mathrm{T}$. asperelum with Vermicompost fertilizer carriers produced the maximum number of seeds per plant 80 seeds / plant followed by $T$. asperelum and $T$. harzianum, and here it is clear that Trichoderma alone is indeed a growth stimulating fungus of peanut plants.

\section{Weight of seeds / plants}

From the results of the study (Table 3), it appears that plants that were treated with Trichoderma with a fertilizer carrier or bioslurry produced a higher seed weight compared to control (only the treatment of fertilizer vermicompost and Biosllury only. This proved that Trichoderma was very potent as a growth stimulator plants and also as natural enemies of pathogens that cause plant diseases. The treatment of $T$. koningii, $T$. asperelum with the vermicompost carrier produced the highest seed weight compared to other treatments followed by T.viride with the bioslurry carrier. 


\section{Yields of peanut /Ha}

In Table 3, it appears that the production of peanuts per $\mathrm{Ha}$, after the plants were given Trichoderma mushrooms with a carrier of fertilizer Vermicompost or bioslurry, obtained that the control treatment which is only fertilized with Vermicompost or bioslurry alone produces low production of only about 1.6 tons while those that get Trichoderma treatment with a cascade or bioslurry carrier is between 2.5 - 3.9 tons per Ha so it is double the control. Table 3 shows that the treatment of T. asperelum, T. koningii and T. harzianum with vermicompost fertilizer carriers can increase soybean yields to nearly 4 tons, followed by $T$. asperelum with bioslurry carriers. So from the results of this study it is clear that the fungus that stimulates plant growth and that is able to increase peanut production is the fungus $T$. asperelum, and $T$. koningii, so it needs to be studied further, what compounds are produced so as to stimulate plant growth

\section{Level of damage of the Striped Virus in peanuts}

Table 4 shows the level of streak virus disease in peanut plants that have received seed treatment and application of vermicompost fertilizer and bioslurry can be seen in Table 4 . In the table it appears that the treatment of vermicompost and bioslurry without given Trichoderma is very sensitive to virus attacks mottled, but $T$. asperelum although it has been given Vermicompost and bioslurry fertilizer, it is the same as the control, so T. asperelum is not good to be used as biological pesticide agent. However, peanut plants that were treated with Trichoderma viride and $T$. harzianum were slightly attacked by the striped virus compared to other treatments, when viewed from the Trichoderma carrier media, it turns out that bioslurry fertilizer carriers produce a percentage of small striped disease compared to Vermicompost fertilizer media,

\section{Intensity of leaf rust disease}

In table 4 it appears that the control plants were only given a vermicompost fertilizer or bioslurry fertilizer, without being given Trichoderma very easily attacked by Belang Virus disease with attack rates of $30.60 \%$ to $28.76 \%$, then leaf rust disease to intensities between 55.79 and $60.45 \%$. But for all treatments that received Trichoderma, the rate of disease attack was far lower than control. From the research results it turns out that Trichoderma asperilium either formulated in vermicompost fertilizers or bioslurry fertilizers has the lowest attack rates of striped virus disease $(3.60 \%$ and $4.13 \%)$ or leaf rust disease with attack intensity of $15.70 \%$ and $14.06 \%$.

From the results of this study it can be concluded that;

After the peanut seeds are given seed treatment, Trichoderma koningii, T.viride, T. asperelum, $T$. reseii and $T$. asperelum $\mathrm{RS}$ formulated in Vermicompost or bioslurry fertilizer are very good in increasing the growth and production of peanuts and increasing resistance plants against striped virus and leaf rust disease compared to Control (only using Vermicompost and bioslurry without Trichoderma)

Trichoderma which is formulated in Vermicompost fertilizer has better ability to increase plant growth compared to bioslurry fertilizer

Trichoderma asperelum is the best Trichoderma if applied to peanut plants because in the formulation with fertilizer Vermicompost produces plant height, number of branches, number of leaves, amount of leaf 
chlorophyll, number of root nodules, fresh plant weight, weight of filled pods, number and weight of planting seeds and cause peanuts can produce 3.9 tons / Ha while Control only 1.65 tons per $\mathrm{Ha}$ as well as if Trichoderma has been formulated in bioslurry fertilizer, peanut plants can produce 3.70 Tons / Ha

4. In terms of increasing disease resistance it turns out that Trichoderma asperilium either formulated in vermicompost fertilizers or bioslurry fertilizers has the lowest attack rates of striped virus disease $(3.60 \%$ and $4.13 \%)$ or leaf rust disease with attack intensity of $15.70 \%$ and $14.06 \%$.

5. In the case of increasing peanut production to reach 3.9 tonnes perha, it is better to use Trichoderma asperelum formulated in vermicompost or bioslurry fertilizer

\section{Acknowledgement}

I would like to thank the Rector of Udayana University for providing research funding through the DIPA PNBP Udayana University TA - 2019 in accordance with the Letter of Appointment for Research Implementation

Number: 551-20 / UN14.4.A / LT / 2019, April 10, 2019

\section{References}

Agrios, GN. 2005. Plant Pathology, Fifth edition.

Alexander, M. 1977. Introduction to Soil Microbiology. John Willey and Son. New York.

Andrianto, T.T. dan N. Indarto, 2004. Budidaya dan Analisis Usaha Tani Kedelai, Kacang Hijau, Kacang Panjang, Absolut, Yogyakarta.

Adisarwanto, 2000. Meningkatkan produksi kacang tanah di lahan sawah dan lahan kering, Penebar Swadaya, Jakarta

Dinarto, W dan D. Asrani 2012. produktivitas kacang tanah di lahankering pada berbagai intensitas penyiangan. Jurnal AgriSain, Hol. 3, No. 4. 33-43.

Doke, N., K. Tomiyama and N. Furuichi. 1982. Elicitation and supression of hypersensitive response in host-parasite specificity. pp 79-96 Dalam Yasuji Asada, W.R. Bushnell, Seiji Ouchi, and C.P. Vance (Eds.) Plant infection, The Physiological and biochemical basis. Japan Scientific Societies Press, Tokyo

Hanuddin, W. Nuryani, E. Silfia, I. Jadnika dan B. Marwoto 2010. Formulasi biopestisida berbahan aktif Bacillus subtilis dan Pseudomonas flourescens dan Corynebacterium sp nonpatogenik untuk mengendalikan penyakit karat pada krisan. J. Hort. 20(3). 247-261. 2010

Hanuddin dan B. Marwoto. 2003. Pengendalian penyakit layu bakteri dan akar gada pada tomat dan Caisim menggunakan Pseudomonas florescens. J. Hort. 13 (2); 58-66.2003.

Hapsoh, 2008. Pidato pengukuhan Guru Besar, Universitas Sumatra Utara, 14 Juni 2008

Harman, G. E. 2000. The myths and dogmas of biocontrol: changes in perceptions derived from research on Trichoderma harzianum strain T-22. Plant Disease 84:377-393.

Hidayat A, Mulyani A. 2002. Lahan Kering untuk Pertanian. Di dalam:

Adimihardja A, Mappaona, Saleh A (Penyunting). Teknologi

Pengelolaan Lahan Kering Menuju Pertanian Produktif dan Ramah

Lingkungan. Bogor: Puslitbangtanak. hlm 134.

Hoerussalam, Aziz Purwantoro, dan Andi Khaeruni 2013. Ketahanan tanaman jagung (Zea mays 1.) terhadap penyakit bulai melalui seed treatment serta 
pewarisannya pada generasi S1. Ilmu

Pertanian Vol. 16 No.2, 2013 : 42 - 59

Gaur, A.C. 1981. Phosphomicroorganism and Varians Transformation in Compost Technology. FAO Project Field Document 13 : 106-111.

Good, RN, Z. Kiraly and KR Wood. 1986. The biochemistry and physiology of plant disease. University of Mssouri, Press. Columbus

Kuc, J. 1983. Induced systemic resistance in plant caused by fungi and bacteria, pp: 192-221 dalam B.J. Deveral (Eds.), The dynamics host devence. Acad. Press, Sydney, New York, London

Kloepper, J.W., Wei, L., Tuzun, S. 2004. Induced systemic resistance to cucumber diseases and increased plant growth by plant growth promoting rhizobacteria under field conditions. Phytopathology. 86: 221-224.

Kuruparan, P. 2005. Vermicomposting as an Eco tool in Sustainable Solid Wate Management.Tamil Nadu: Anna University

Marzuki, H.A.R. 2007. Bertanam Kacang Tanah. Edisi Revisi. Jakarta : Penebar Swadaya. 43 hal.

Munroe, G. 2003.Manual of On-Farm Vermicomposting and Vermiculture. Canada: Organic Agriculture Centre

Nurhayati. 2009. Pengaruh Pupuk Kalium Pada Ketahanan Kacang Tanah Terhadap Bercak Daun Cercospora. Jurnal Agriculture Vol. 13. No. 3, November 2008-Februari 2009 ISSN: $1412-4262$.

Purwaningsih, 2003. Pengaruh mikroba tanah terhadap pertumbuhan dan hasil panen kedelai (Glycine max L). Berita Biologi 5; 373-378.

Papavizas, G.C. 1985. Trichoderma harzianum and Gliocladium: Biology, Ecology and Potensial for Biological Control of Soiborne Diseases. Laboratory Plant Protection Institut
Agriculture Research Service, US Department of Agriculture Research, Beltsville, Maryland.

Rachman. S, (2002), Penerapan Pertanian Organik, Penerbit Kanisius, Yogyakarta.

Rao, N.S. 1994. Mikroorganisme Tanah dan Pertumbuhan Tanaman. Edisi Kedua. Jakarta: UI-Press.

Rukmana, S. K. dan Y. Yuniarsih. 1996. Kedelai, Budidaya Pasca Panen. Penerbit Kanisius. Yogyakarta. 92 hal

Sudantha, I. M. dan NML Ernawati. 2014. Peran Jamur Endofit Trichoderma spp. Untuk Meningkatkan Ketahanan Terinduksi Bibit Pisang Terhadap Penyakit Layu Fusarium. Agroteksos. Vol. 24: 3. Hal. 145-152.

Syahri. 2011. Potensi pemanfaatan cendawan Trichoderma spp. sebagai agens pengendali penyakit tanaman di lahan rawa lebak. Balai pengkajian teknologi pertanian (BPTP). Sumatera selatan

Susanto, R. 2002. Penerapan Pertanian Organik. Kanisius. Yogyakarta

Surtiningsih, T; Farida dan T. Nurhayati. 2009. Biofertilisasi Rhizobium pada tanaman kedelai (Glycine max (L). MERR). Berk.Penel. Hayati. 15 (1-5. 2009.

Sumarno. 1987. Tehnik Budidaya Kacang Tanah. Bandung : Sinar Baru. 79 hal.

Taufik. M, A, Rahman, A. Wahab, dan SH.Hidayat . 2010. Mekanisme ketahanan terinduksi oleh plant growth promoting rhizobakteria (PGPR) pada tanaman cabai terinfeksi cucumber mosaic virus (CMV). J. Hort. 20(3). 274-283.

Tomiyama, K. 1982. Hypersensitive cell death. Its significance and physiology, pp. 329-344 dalam Yasuji Asada, W.R. Bushnell, Seiji Ouchi, and C.P. Vance (Eds.) Plant infection, the pysiological and biochemical basis. Japan Scientific 
Societies Press, Tokyo

Tiunov, A.V., and T.G.Dobrovolskaya. 2002.

Fungal and Bacterial Communities in

Lumbricus terrestries Burrow Walls : A

Laboratory

Pedobiological,46 : 595-605.

Waluyo, L., 2008, Teknik Metode Dasar

Mikrobiologi, Universitas

Muhamadiyah Malang Press, Malang.

Widawati, S. dan Suliasih, 2006,

Populasi Bakteri dan pemberian kapur terhadap daya saing dan pertumbuhan kacang tanah (Arachis hypogaea, L), Skripsi Fakultas Pertanian IPB Bogor, tidak dipublikasi.

Zhang, S., Reddy M.S., Klopper J.W. 2002. Development of assay for assessing induced systemic resistance by plant growth-promoting rhizobacteria against blue mold of tobacco. Biol Control. 23: 79-86.

Wijaya, Aandi 2011. Pengaruh pemupukan

\section{How to cite this article:}

Made Sudana, I. and Gusti Ngurah Raka, I. 2020. Seeds Treatment Using Trichoderma spp. Formulated in bioslurry and Vermicompost to Induct the Resistance of the Peanut (Arachis hypogaea. 1) Diseases. Int.J.Curr.Microbiol.App.Sci. 9(10): 1253-1265.

doi: https://doi.org/10.20546/ijcmas.2020.910.151 